\title{
Localization of the Alkaline Phosphatase and 5'-Nucleotidase Activities of the Diatom Phaeodactylum tricornutum
}

\author{
By K. J. FLYNN, * H. ÖPIK AND P. J. SYRETT \\ Plant and Microbial Metabolism Research Group, School of Biological Sciences, \\ Unicersity College of Swansea, Singleton Park, Swansea SA2 8PP, UK
}

(Reccived 23 July 1985; revised 9 September 1985)

\begin{abstract}
Intact cells of phosphate-depleted Phaeodactylum tricornutum possessed non-specific alkaline phosphatase (EC 3.1.3.1; PMEase) and 5'-nucleotidase (EC 3.1.3.5; 5'-NDase) activities; there was also an extracellular PMEase. The optimum $\mathrm{pH}$ for the cell-bound PMEase was $>10 \cdot 3$, and for the 5'-NDase was 9-9.5. The extracellular PMEase had an optimum pH $>10 \cdot 3$ and accounted for $>30 \%$ of the total PMEase activity at this $\mathrm{pH}$; there was no extracellular 5 NDase activity. The activities of these enzymes increased during phosphate-deprivation, but the rate of AMP hydrolysis (by the action of both PMEase and 5'-NDase) always exceeded that of $p$-nitrophenylphosphate at the physiological $\mathrm{pH}$ (for a marine organism) of $8-8 \cdot 5$. By the use of differential centrifugation after cell disruption in a French pressure cell, a highly purified fraction of cell walls was prepared. This fraction was virtually devoid of membranous material as viewed by electron microscopy, and exhibited PMEase, but no 5'-NDase activity. By using a different centrifugation procedure after disruption by shaking with glass beads, a microsomal fraction (pelleted by forces of $14000-156000 \mathrm{~g}$ ) was prepared. This fraction was free of cell wall fragments as viewed by electron microscopy, and exhibited 5'-NDase activity but no PMEase activity. It is concluded that the PMEase was associated with cell walls, whilst the membranebound 5'-NDase which sedimented as vesicles in the microsomal fraction was associated with plasma membranes.
\end{abstract}

\section{INTRODUCTION}

Although severe phosphate-limitation of the growth of marine algae may not often occur (Goldman et al., 1979), there are numerous reports of natural phytoplankton communities displaying symptoms of phosphate-deprivation, particularly in coastal waters (e.g. Chiaudani \& Vighi, 1982: Myklestad \& Sakshaug, 1983; Sakshaug et al., 1984; Smith \& Kalff, 1981). Phosphate-limitation may be due to excess demands by the algae, bacterial competition (Rhee, 1972), or to removal of organic phosphates by dissolved humic materials (Stewart \& Wetzel, 1982). The symptom often used to diagnose phosphate-deprivation of algal cells is an increased activity of alkaline phosphatase, as measured by the release of inorganic phosphate $\left(\mathrm{P}_{\mathrm{i}}\right)$ from $p$ nitrophenylphosphate (pNPP) (Kuenzler \& Perras, 1965) or by fluorimetric measurements of the hydrolysis of 3-O-methylfluorescein phosphate (Perry, 1972).

The development of alkaline phosphatase activity by the marine diatom Phaeodactylum tricornutum following phosphate-deprivation has been reported (Kuenzler \& Perras, 1965), as has the utilization of glucose 6-phosphate (Kuenzler, 1965). The diatom has also been used as a model organism by Chiaudani \& Vighi (1982), who reported the extracellular release of phosphatase activity during phosphate-deprivation.

The development of uptake systems for nitrogenous compounds in P. tricornutum has been studied in some detail (see Flynn \& Syrett, 1985, and references therein) but it is not known if

\footnotetext{
Abbreviations: 5'-NDase, 5'-nucleotidase; NMP, nucleoside 5'-monophosphate; pNPP, p-nitrophenylphosphate; PMFase, alkaline phosphatase.
} 
new transport proteins are synthesized during nitrogen-deprivation or if existing proteins are activated. To study this problem it is necessary to isolate plasma membranes from nitrogenreplete and nitrogen-depleted cells and then to look for any differences in the protein composition of the membranes. The work described in this paper arose from attempts to use phosphatase activities as markers for membranes during their isolation. The study characterizes more precisely the previously described alkaline phosphatase activities and also reports, for the first time in a marine alga, the presence of a $5^{\prime}$-nucleotidase in intact cells.

In this paper, the term PMEase describes a non-specific alkaline phosphatase (EC 3 1.3.1), $5^{\prime}$-NDase describes a 5'-nucleotidase (EC 3.1.3.5), and NMPase describes enzymes liberating $P_{i}$ from a nucleoside 5'-monophosphate (NMP) (i.e. 5'-NDase with or without PMEase activity).

\section{METHODS}

Growth and preparation of organism. Phaeodactylum tricornutum Bohlin (strain 1052/6 of the Culture Centre of Algae and Protozoa, UK) was grown in a modified ASP-2 medium (Provasoli et al., 1957) at $\mathrm{pH} 8.5$ in continuous light $\left(25 \mathrm{~W} \mathrm{~m}^{-2}, 400-700 \mathrm{~nm}\right)$ and aerated with $0.05 \%(\mathrm{v} / \mathrm{v}) \mathrm{CO}_{2}$ as previously described (Flynn \& Syrett, 1985). Three different phosphate concentrations were used: phosphate-free, phosphate-deficient $\left(0 \cdot 115 \mathrm{mM}-\mathrm{K}_{2} \mathrm{HPO}_{4}\right)$ and phosphate-sufficient $\left(0.46 \mathrm{mM}-\mathrm{K}_{2} \mathrm{HPO}_{4}\right)$; all media contained $20 \mathrm{~mm}-\mathrm{KNO}_{3}$. The $\mathrm{N}: \mathrm{P}$ ratio in the phosphate-sufficient medium was 43 ; the $\mathrm{N}$-source was not depleted and cells did not show signs of phosphatedeficiency as indicated by PMEase activity. Cells grew poorly in the phosphate-free medium ( $3-4$ doublings), presumably using reserves of phosphate gained during growth in stock cultures. Cells grew equally well on the other media during the $4 \mathrm{~d}$ growth period.

After 3-4 d growth, cells were harvested by centrifugation at $4000 \mathrm{~g}$, washed and resuspended in $550 \mathrm{~mm}$ sorbitol buffered by $50 \mathrm{mM}$-Tris base at $\mathrm{pH} 8.0$. For assays of the extracellular PMEase activity, cells were grown for $3 \mathrm{~d}$ in phosphate-free medium. A portion of the culture was harvested, the cells were resuspended in fresh medium, and the old medium was then centrifuged at $8000 \mathrm{~g}$ for $10 \mathrm{~min}$ to remove any remaining cells or debris. The resultant supernatant was concentrated by the use of a Millipore CX-30 immersible ultrafiltration unit (cut-off $M_{r}$ 30000).

Preparation of subcellular fractions. A $450 \mathrm{ml}$ culture, grown in phosphate-deficient medium in a Dreschel bottle for $4 \mathrm{~d}$ (typically $3.5 \mathrm{~g}$ wet weight cells), was harvested by centrifugation at $4000 \mathrm{~g}$, and washed twice in ice-cold wash buffer containing $550 \mathrm{~mm}$-sorbitol and $50 \mathrm{~mm}$-Tris base $(\mathrm{pH} 8)$. The cells were resuspended in an ice-cold disruption buffer containing $550 \mathrm{~mm}$-sorbitol, $50 \mathrm{~mm}$-Tris base ( $\mathrm{pH} 8), 10 \mathrm{mM}$-EGTA, $2.5 \%(\mathrm{w} / \mathrm{v})$ polyvinylpyrrolidone (average $M_{\mathrm{r}} 40000$ ) $, 2.5 \mathrm{mM}-\mathrm{K}_{2} \mathrm{~S}_{2} \mathrm{O}_{5}, 2 \mathrm{mM}$-salicylhydroxamic acid and $1 \mathrm{mM}$-phenylmethylsulphonyl fluoride. This buffer is essentially that used by Yoshida et al. (1983), who discussed the functions of the components.

Two methods of cell disruption were used. Firstly the cells, suspended in disruption buffer, were disrupted by shaking with no. 10 ballotini beads ( $3.5 \mathrm{~g}$ wet weight cells $+3.5 \mathrm{ml}$ buffer $+3.5 \mathrm{ml}$ ballotini) at $4000 \mathrm{r}$.p.m. in a $50 \mathrm{ml}$ Duran bottle, for $3 \times 20$ s periods ( 10 s intervals) in a cooled Braun MSK homogenizer. After disruption, the extract was made up to $20 \mathrm{ml}$ with disruption buffer and separated from the ballotini by Pasteur pipette. Alternatively, cells suspended in $10 \mathrm{ml}$ disruption buffer $+1 \mathrm{~g}$ sorbitol (in order to decrease the osmotic potential) were disrupted by three passes at $100 \mathrm{MPa}$ through an ice-cold French pressure cell. The extract was then diluted to $20 \mathrm{ml}$ with distilled water. All the cells were disrupted by the pressure cell and $85-95 \%$ by the homogenizer. The disrupted cells were subjected to differential centrifugation according to the schemes in Fig. 1. The scheme in Fig. I (a) was modified from methods used by Sullivan \& Volcani (1974) and Yoshida et al. (1983). Centrifugation was done with a Beckman J2-21 centrifuge with a JA 20 rotor, and a Beckman L5-65B ultracentrifuge with a 65Ti rotor. The designation of the fractions is only approximate; the contents would depend largely on the force used during disruption and the density of the suspending solution.

Enzyme assays. For assays in intact cells, a volume of cell suspension (50 or $100 \mu \mathrm{l})$ was added to $800 \mu \mathrm{l}$ phosphate-free growth medium maintained at the required $\mathrm{pH}$ by $100 \mathrm{mM}$-glycine/ $\mathrm{NaOH}$ ( $\mathrm{pH}$ range $8 \cdot 5-10 \cdot 5$ ). The $\mathrm{NaCl}$ content of the medium was adjusted so as to maintain a $\mathrm{Na}^{+}$concentration of $250 \mathrm{~mm}$. The final cell density was $1-5 \times 10^{6} \mathrm{ml}^{-1}$. Enzyme activities in subcellular fractions were measured in a buffer containing $200 \mathrm{~mm}-\mathrm{KCl}, 8 \mathrm{~mm}-\mathrm{MgCl}$ and $100 \mathrm{~mm}-\mathrm{glycine} / \mathrm{NaOH}(\mathrm{pH} 8 \cdot 5-10 \cdot 5)$ with $\mathrm{NaCl}$ added to maintain a final concentration of $200 \mathrm{~mm}-\mathrm{Na}^{+}$. The final protein content was $30-50 \mu \mathrm{g} \mathrm{ml}^{-1}$.

The substrates (sodium salts) were added in a volume of $100 \mu \mathrm{l}$ to give a final concentration of $2.5 \mathrm{~mm}$. 5 'Nucleotides ( $25 \mathrm{~mm}$ ) were dissolved in $25 \mathrm{~mm}-\mathrm{NaOH} / \mathrm{Tris}$, giving a pH of 6-7, to counteract the acidity of these compounds when dissolved in water.

Enzymes were assayed in $1.5 \mathrm{ml}$ microtubes at $35^{\circ} \mathrm{C}$ for $10-30 \mathrm{~min}$. At intervals, $50 \mu \mathrm{l}$ samples were taken for the determination of $P_{i}$. The acidity of the reagents used in the $P_{i}$ assay terminated the enzyme assay and killed the cells. 
(a)

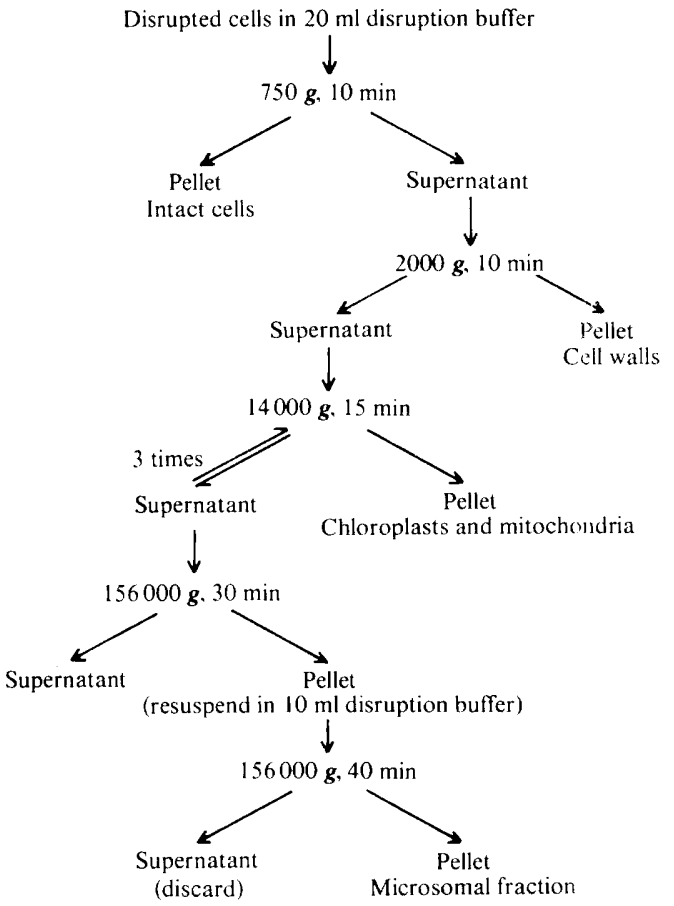

(b)

Cells ( $3.5 \mathrm{~g}$ wet wt) in $10 \mathrm{ml}$ disruption buffer $+1 \mathrm{~g}$ sorbitol; disrupt by 3 passes through a French pressure cell at $100 \mathrm{MPa}$ Dilute with $10 \mathrm{ml}$ distilled water

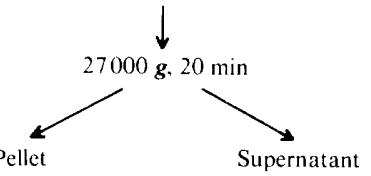
(resuspend in $20 \mathrm{ml}$ buffer containing $10 \mathrm{~mm}$-Tris, pH 9 , (discard)

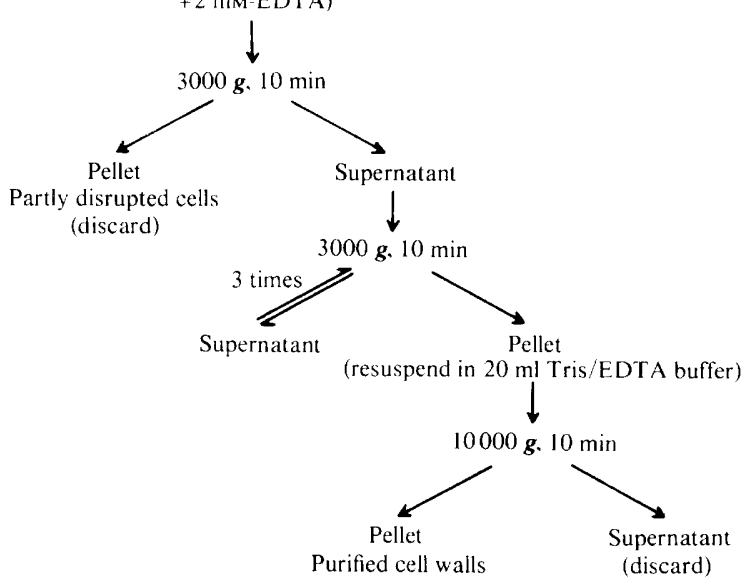

Fig. 1. Schemes for the differential centrifugation of disrupted cells. (a) For the preparation of a cell wall-free microsomal fraction, and $(b)$ for the preparation of a membrane-free cell wall fraction.

After the final samples had been taken. the $\mathrm{pH}$ of the assay suspension was measured using a Russell CTWL pH probe; it is these values of $\mathrm{pH}$ rather than the $\mathrm{pH}$ of the assay buffers, which are shown in the graphs.

Assay for $P_{1}$. A method modified from that of Lanzetta et al. (1979) was used, in which $5 \%(\mathrm{v} / \mathrm{v})$ Triton X-100 was substituted for the original detergent. The colour reagent consisted of $0.045 \%$ malachite green mixed with $4.2 \%$ $(\mathrm{w} / \mathrm{v})$ ammonium molybdate in $4 \mathrm{M}-\mathrm{HCl}$ in the ratio $3: 1$ and filtered through a Whatman no. 3 paper. Shortly before use $(<2 \mathrm{~h}), 200 \mu \mathrm{l} 5 \%(\mathrm{v} / \mathrm{v})$ Triton X-100 was mixed with $10 \mathrm{ml}$ of the colour reagent.

The sample, containing a maximum of $10 \mathrm{nmol} \mathrm{P}_{\mathrm{i}}$ in a volume of 50 or $100 \mu \mathrm{l}$, was forcibly injected from a microsyringe into $800 \mu \mathrm{l}$ of the colour reagent in a $1.5 \mathrm{ml}$ microtube. After $1 \mathrm{~min}, 100 \mu \mathrm{l} 34 \%$ (w/v) sodium citrate was added, mixed and left to stand for at least $30 \mathrm{~min}$ after which the colour was stable for many hours, even after the addition of $100 \mathrm{nmol} \mathrm{P}_{i}$ (such as could occur during the acid-hydrolysis of NMPs). The $A_{6,0}$ was measured in at Cecil Instruments CF 272 linear read-out UV/VIS spectrophotometer. Blanks were zero time enzyme assays.

Tests were done to ascertain if the presence of cells affected measurements of the $P_{1}$ content of the enzyme assay mixture; $P$, measurements were made after the incubation period with the cells in suspension and after the cells had been removed by a $10 \mathrm{~s}$ spin at $8700 \mathrm{~g}$ in a Beckman $\beta$ microfuge. There was a small consistent difference between these values which was attributed to the $O D$ of the cells at $660 \mathrm{~nm}$. Routinely the samples used for the determination of $\mathrm{P}$, contained cells in suspertsion.

$P_{i}$ measurements were taken at 5 or 10 min intervals: reaction rates were linear with time and enzyme concentration. Assays were duplicated at each condition of $\mathrm{pH}$ and reproducibility was good (usually $<5 \%$ difference).

Protein was assayed by the BioRad microassay with bovine serum albumin as a standard. All experiments were done on at least three separate occasions. Representative data are presented; the results were highly reproducible.

Electron microscopy: The pellets were fixed in $3 \%(\mathrm{v} / \mathrm{v})$ ice-cold glutaraldehyde in $0.05 \mathrm{M}$-potassium phosphate buffer $(\mathrm{pH} 7 \cdot 1)$, containing $10^{\circ}{ }_{0}(\mathrm{w} / \mathrm{v})$ sucrose; only the cell wall pellets were resuspended. After $1 \mathrm{~h}$ at about $5{ }^{\circ} \mathrm{C}$, fixation was continued at room temperature for a further $1 \mathrm{~h}$. All subsequent steps were done at room temperature, re-pelleting the material as necessary. Three 15 min washes were given in the phosphate buffer with $13.5 \%(\mathrm{w} / \mathrm{v})$ sucrose, and then the samples were post-fixed for $2 \mathrm{~h}$ in $2 \%(\mathrm{w} / \mathrm{v})$ osmium tetroxide in the phosphate buffer. The material was dehydrated in an ethanol series and embedded in white resin, using hard grade for the cells walls and soft grade for the membrane fractions. The resin was polymerized at $60^{\circ} \mathrm{C}$ for $20 \mathrm{~h}$. Sections were cut on an LKB Ultrotome and post-stained for $90 \mathrm{~min}$ with $1 \%$ aqueous uranyl acetate, followed by $8 \mathrm{~min}$ in $0.2 \%$ alkaline lead 
citrate. For the cell wall fractions, small portions were also removed from the glutaraldehyde-fixed, buffer-washed pellets, diluted with distilled water, and droplets placed on collodion-coated grids for about $30 \mathrm{~s}$ before being drained off. The dried grids were thoroughly washed with distilled water and were examined unstained. An AEI Corinth 275 electron microscope at $60 \mathrm{kV}$ was used for the observations.

Chemicals. Fixatives and stains for electron microscopy were obtained from TAAB Laboratories and the resin was purchased from the London Resin Compan\%. Malachite green microscopical stain was obtained from BDH: all other chemicals were from Sigma.

\section{RESULTS}

After growth in phosphate-free medium, both the cells and the medium contained PMEase activity with a $\mathrm{pH}$ optimum exceeding $10 \cdot 3$. In addition, there was a cell-bound NMPase activity, which was absent from the medium, with an optimum $\mathrm{pH}$ of 9-9.5 (Fig. 2). A proportion of the hydrolysis of AMP would have been catalysed by the activity of the PMEase and the remainder by a $5^{\prime}$-NDase (the total activity being termed NMPase). The hydrolysis of AMP by extracellular enzymes was catalysed by a PMEase only; at no pH value did the rate of hydrolysis of AMP by these enzymes exceed that of pNPP.

There was no PMEase activity in the filtrate after the use of a Millipore CX-30 ultrafiltration unit, suggesting that the $M_{\mathrm{r}}$ of this enzyme exceeded 30000 . The amount of protein in the medium, even after a $10 \times$ concentration, was below the level of detection of the BioRad microassay $\left(<0 \cdot 1 \mu \mathrm{g} \mathrm{ml}^{-1}\right)$.

As noted by Kuenzler \& Perras (1965), the PMEase activity of the cells increased after phosphate-deprivation. The activities of the PMEase in cells grown in phosphate-sufficient and in phosphate-free culture for $4 \mathrm{~d}$ were 10 and $60 \mathrm{nmol} \mathrm{P}_{\mathrm{i}}\left(10^{6} \text { cells }\right)^{-1} \mathrm{~h}^{-1}$ respectively (measured at $\mathrm{pH} 10 \cdot 5$ ). In addition there was a concurrent increase in the NMPase activity; values for the NMPase activities of these cells were 12 and $160 \mathrm{nmol} \mathrm{P}_{\mathrm{i}}\left(10^{6} \text { cells }\right)^{-1} \mathrm{~h}^{-1}$ respectively (measured at $\mathrm{pH} 9 \cdot 25$ ). The NMPase activity of the cells was always 3-4 times greater than that of the PMEase and this difference was greatest at $\mathrm{pH} 9-9 \cdot 5$.

After washing and resuspending the cells in fresh growth medium or in $550 \mathrm{~mm}$-sorbitol, the PMEase activity per cell decreased; the NMPase activity did not (compare the relative activities of PMEase and NMPase in Figs 2 and $3 b$ ). Presumably at least some of the PMEase activity in the original medium was due to the same enzyme that was originally attached to the cell.

A range of phosphomonoesters and NMPs were tested as substrates over a range of $\mathrm{pH}$ values (Fig. 3). Tests were also done over a lower range of $\mathrm{pH}(6 \cdot 5-9 \cdot 5$, buffered by $100 \mathrm{mM}$-Tris/MES); maximum activities were at a $\mathrm{pH}>8.5$, arid there were no peaks of activity below this value. Of the non-nucleotide phosphates, hydrolysis of pNPP was fastest, with thiamin pyrophosphate, glucose 6-phosphate and $\beta$-glycerophosphate being hydrolysed at much the same rates (Fig. $3 a$ ). $\alpha$-Glycerophosphate was hydrolysed at the same rate as $\beta$-glycerophosphate (not shown). The phosphodiesterase substrate, bis-( $p$-nitrop nenyl) phosphate, was hydrolysed only slowly. All the NMPs were hydrolysed much faster than any of the non-nucleotide phosphates (Fig. $3 b$ ) although hydrolysis of the NMPs was probably catalysed by both PMEase and 5'-NDase. AMP was always hydrolysed at a greater rate than the other nucleotides, with GMP giving the lowest rate. There was a small but consistent difference between the activities with the purine nucleotides (AMP and GMP) and the pyrimidine nucleotides (CMP, TMP and UMP) with respect to $\mathrm{pH}$. This was most apparent after subtraction of the PMEase component (assuming that the PMEase activity was similar for all of the NMPs and for pNPP, as it was for AMP; Fig. 9 ); the 5'-NDase appeared to have a slightly lower $\mathrm{pH}$ optimum for the purine nucleotides.

Due to the limitation of $\mathrm{P}_{\mathrm{i}}$ detection by colorimetric methods, the minimum substrate concentration that maintained a linear rate of enzymic reaction and gave a sufficient $P_{i}$ for detection (a minimum of $0.2 \mathrm{nmol}$ in a $100 \mu 1 \mathrm{lsample}$ ) was $20 \mu \mathrm{M}$. Attempts to measure the $K_{\mathrm{m}}$ of the PMEase and NMPase were unsatisfactory, but the $K_{\mathrm{m}}$ for the PMEase using pNPP as a substrate was about $50 \mu \mathrm{M}$. The $K_{\mathrm{m}}$ for NN Pase with AMP as a substrate was less than $25 \mu \mathrm{M}$, with the rate at this concentration being about $75 \%$ of $V_{\max }$. 


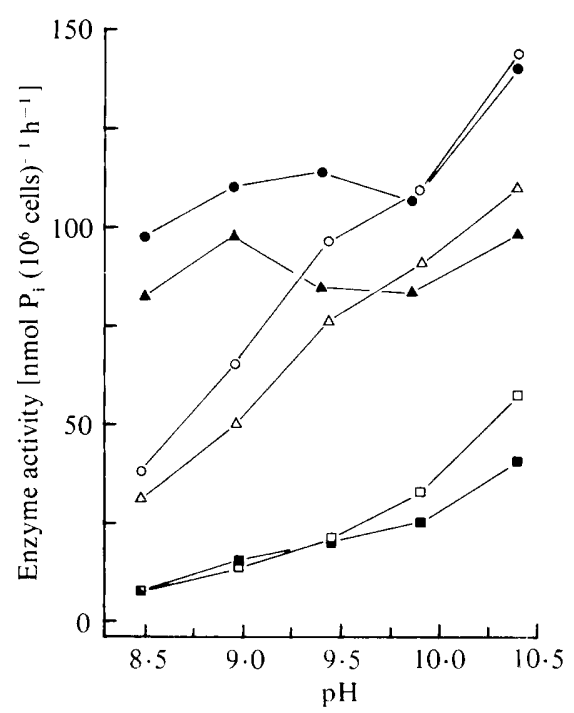

Fig. 2

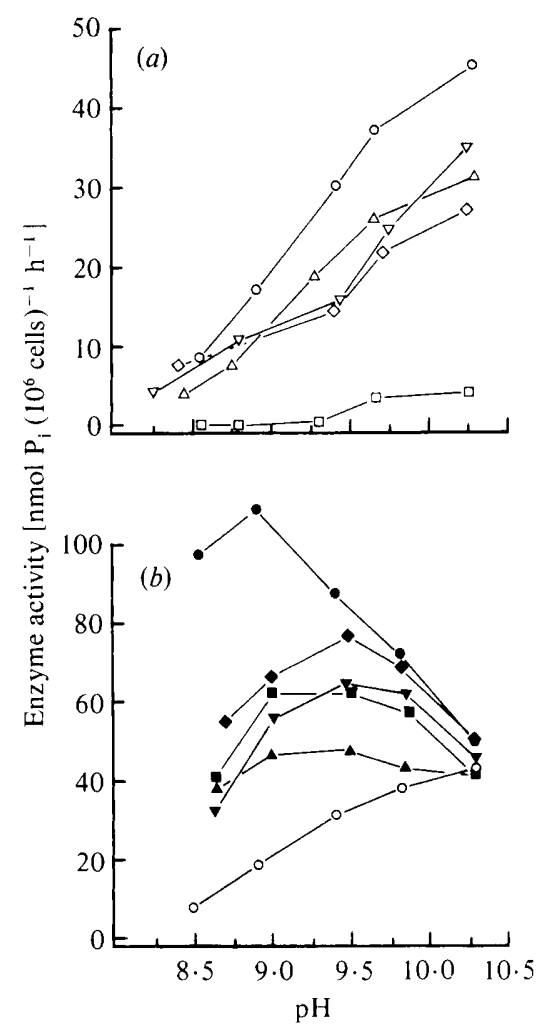

Fig. 3

Fig. 2. PMEase and NMPase activities in phosphate-deprived cells and the growth medium. Cells were grown in phosphate-free medium for $4 \mathrm{~d}$. The rates of hydrolysis of $2.5 \mathrm{~mm}$-pNPP (open symbols) and of $2.5 \mathrm{mM}$-AMP (closed symbols) were measured using a portion of the whole culture, i.e. cells + medium $(\bigcirc, O)$, cells only after centrifugation and resuspension in fresh phosphate-free medium $(\triangle$. $\Delta$ ) and the culture medium after removal of the cells ( $\square$

Fig. 3. PMEase and NMPase activities of phosphate-deprived cells over the pH range $8 \cdot 5$ to 10.5. Cells were grown in phosphate-deficient culture for $4 \mathrm{~d}$, washed and resuspended in $550 \mathrm{~mm}$-sorbitol buffered by $100 \mathrm{~mm}$-glycine $\mathrm{NaOH}$. Substrates were $(a)$ pNPP $(\mathrm{O})$, $\beta$-glycerophosphate $(\triangle)$, glucose 6phosphate $(\nabla)$, thiamin pyrophosphate $(\diamond)$, bis- $(p$-nitrophenyl) phosphate $(\square)$, and $(b)$ AMP $(\bigcirc)$, GMP $(\boldsymbol{\Delta}), C M P(\boldsymbol{\square})$, TMP $(\diamond)$ or UMP $(\nabla)$ at final concentrations of $2.5 \mathrm{~mm}$.

All the enzyme assays were done at $35^{\circ} \mathrm{C}$. The reaction rates at $20^{\circ} \mathrm{C}$ (the temperature at which the cells were grown) were about $40 \%$ of the values at $35^{\circ} \mathrm{C}$. The value for $Q_{10}$ between 20 and $30^{\circ} \mathrm{C}$ was 1.8 for both the PMEase (pNPP as substrate) and the NMPase (AMP as substrate) at $\mathrm{pH} 8.5$ (the optimum growth $\mathrm{pH}$ for this strain of $P$. tricornutum).

A comparison of the PMEase and NMPase activities of phosphate-deprived cells before and after disruption showed that, although reaction rates increased after disruption (Table 1), the pH optima remained essentially the same (compare Figs 3,8 and 9). After the differential centrifugation (Fig. 1 a) of cells disrupted by the homogenizer, the distribution of the PMEase and 5'-NDase activities differed (Table 1). Whereas a considerable proportion ( $>60 \%$ ) of the $5^{\prime}$ NDase activity was present in the microsomal fraction and in the supernatant, virtually none of the PMEase was located in these fractions (Table $1 a$ ). Most of the PMEase activity was located in the chloroplast and mitochondria fraction (Table $1 a$ ), however, the highest specific activity was in the cell wall fraction (Table $1 b$ ). The highest specific activity for the 5 -NDase was in the microsomal fraction (Table $1 b$ ). The highest absorbance at $670 \mathrm{~nm}$ (indicative of the presence of chlorophyll $a$ ) was in the chloroplast and mitochondria fraction (Table $1 a$ ). 
Table 1. Distribution of PMEase, NMPase and 5'-NDase activities in fractions after differential centrifugation

Cells were disrupted by shaking with glass beads in a Braun MSK homogenizer and the extract was subjected to differential centrifugation according to the scheme in Fig. $1(a)$. Enzymes were assayed at pH 9.5 with pNPP or AMP $(2.5 \mathrm{~mm})$ as substrates. $P_{i}$ was measured in duplicate at 0,5 and $10 \mathrm{~min}$. Activities of $5^{\prime}$-NDase were calculated by subtraction of the PMEase from the NMPase activities. Total activities $(a)$ and specific activities $(b)$ are presented from a typical experiment; -, not applicable.

(a) Total activities

\begin{tabular}{|c|c|c|c|c|c|}
\hline \multirow{2}{*}{$\begin{array}{c}\text { Wet wt } \\
\text { (g) }\end{array}$} & \multirow{2}{*}{$\begin{array}{c}\text { Percentage } \\
\text { chl } a \\
\text { at } A_{670}\end{array}$} & \multirow{2}{*}{$\begin{array}{l}\text { Percentage } \\
\text { protein }\end{array}$} & \multicolumn{3}{|c|}{$\begin{array}{c}\text { Phosphatase activity } \\
{\left[\text { nmol } P_{i}\left(10^{6} \text { cells }\right)^{-1} h^{-1}\right]}\end{array}$} \\
\hline & & & PMEase & NMPase & $5^{\prime}$-NDase \\
\hline 3.45 & - & - & 36.9 & 130 & $93 \cdot 1$ \\
\hline- & 100 & 100 & $46 \cdot 0$ & 173 & $127 \cdot 0$ \\
\hline 0.58 & $17 \cdot 4$ & $7 \cdot 2$ & $8 \cdot 2$ & 16 & $7 \cdot 8$ \\
\hline 0.62 & $9 \cdot 2$ & $4 \cdot 5$ & $9 \cdot 3$ & 12 & $2 \cdot 7$ \\
\hline 1.79 & $57 \cdot 0$ & $44 \cdot 6$ & $33 \cdot 2$ & 41 & $7 \cdot 8$ \\
\hline 0.62 & 11.4 & $12 \cdot 7$ & 0.3 & 28 & $27 \cdot 7$ \\
\hline- & 5.0 & $31 \cdot 0$ & 1.0 & 56 & $55 \cdot 0$ \\
\hline
\end{tabular}

(b) Specific activities

Fraction

Total cell smash

Intact cells

Walls

Chloroplasts and mitochondria

Microsomal

Supernatant

\begin{tabular}{|c|c|c|}
\hline \multicolumn{3}{|c|}{$\begin{array}{c}\text { Specific activity } \\
{\left[\text { nmol } P_{\mathrm{i}}(\mu \mathrm{g} \text { protein })^{-1} \mathrm{~h}^{-1}\right]}\end{array}$} \\
\hline PMEase & NMPase & $5^{\prime}$-NDase \\
\hline $6 \cdot 8$ & $25 \cdot 6$ & $18 \cdot 8$ \\
\hline 18.8 & $36 \cdot 3$ & $17 \cdot 5$ \\
\hline 33.0 & $40 \cdot 8$ & $7 \cdot 7$ \\
\hline $12 \cdot 2$ & 14.9 & $2 \cdot 7$ \\
\hline 0.4 & $35 \cdot 7$ & $35 \cdot 3$ \\
\hline 0.5 & $29 \cdot 5$ & $29 \cdot 0$ \\
\hline
\end{tabular}

Electron micrographs of the microsomal fraction from cells disrupted by the homogenizer showed the absence of cell wall fragments (Fig. 4). Examination of the cell wall fraction, however, revealed the presence of almost intact valves (Fig. 5), even intact cells, and thin sections of this material (not illustrated) showed membranous material still within the valves.

To fragment the cell walls more thoroughly, cells were disrupted in a pressure cell. The differential centrifugation scheme (Fig. $1 b$ ) now yielded a cell wall fraction of great purity as judged by electron microscopy (Figs 6 and 7). Very little membranous material was seen in this preparation. The wall fragments produced after disruption with the pressure cell were very much smaller than those from homogenized cells (compare Figs 5 and 6).

Enzyme assays of the microsomal fraction of cells disrupted by the homogenizer (shown to contain no cell wall fragments; Fig. 4), and of the cell wall fraction of cells disrupted with the pressure cell (shown to contain no membranous material; Fig. 7) showed that PMEase activity was associated with cell walls (Fig. 8) and that the 5'-NDase was associated with membranes (Fig. 9).

\section{DISCUSSION}

Intact cells of phosphate-deficient $P$. tricornutum had two types of phosphatase activity: a non-specific PMEase and a 5'-NDase. Both developed in response to phosphate-deficiency, but the $5^{\prime}$-NDase activity was always greater than that of the cell-bound PMEase at the 

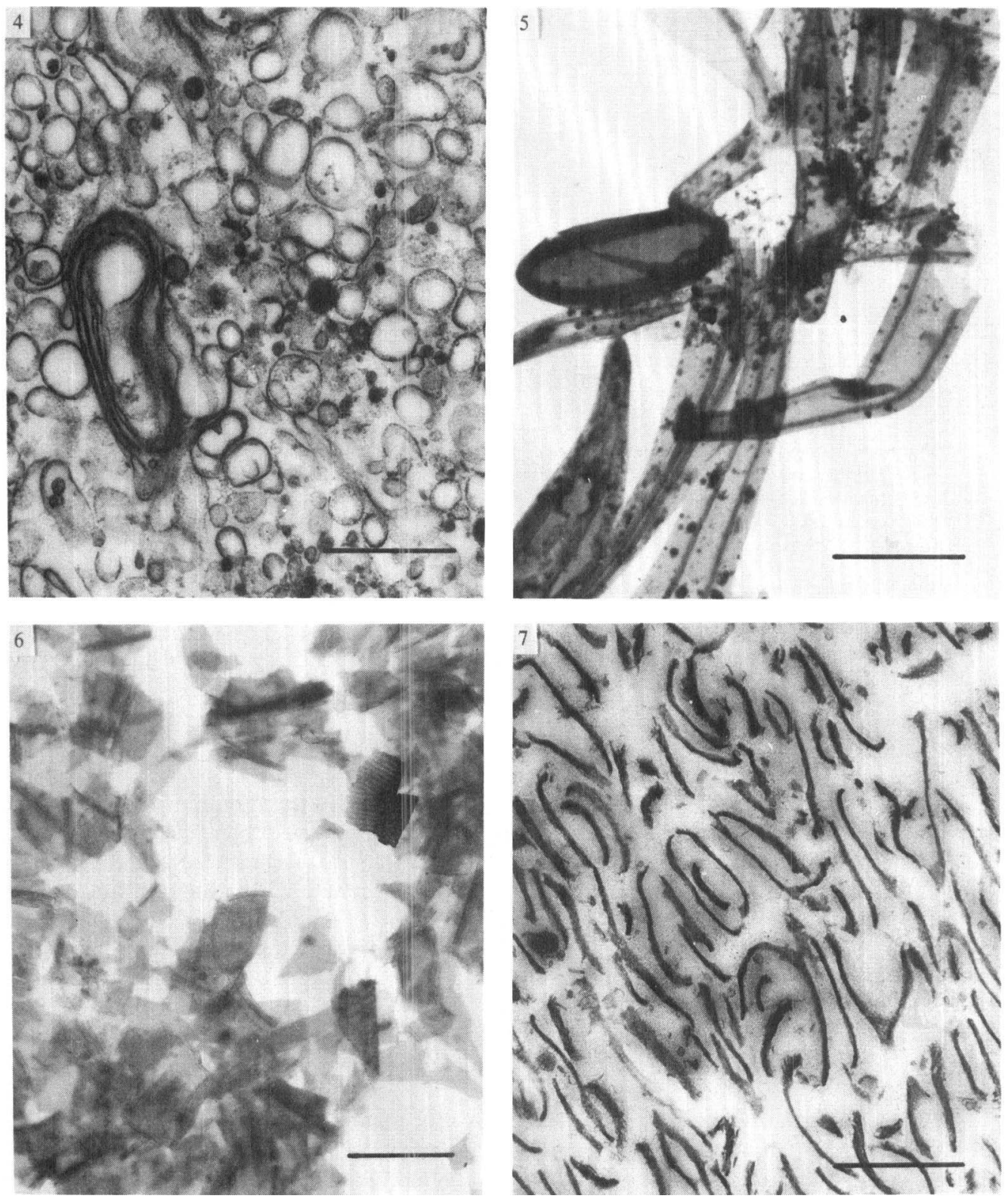

Fig. 4. Microsomal pellet, showing membranous vesicles; the central group of concentric membranes suggests swollen thylakoids. Bar, $0.5 \mu \mathrm{m}$.

Fig. 5. Cell wall fraction prepared by homogenization, unsectioned. Large pieces of cell valves are present, contaminated with electron-dense material from cell contents. Bar, $5 \mu \mathrm{m}$.

Fig. 6. Cell wall fraction prepared by pressure cell, unsectioned. The material is thoroughly broken up (note magnification is twice that of Fig. 5) and there is little evidence of cytoplasmic contamination. Bar, $2 \mu \mathrm{m}$.

Fig. 7. Cell wall fraction prepared by pressure cell, thin section. There is practically nocontamination with cell contents or membranous material. Bar, $(0.5 \mu \mathrm{m}$. 


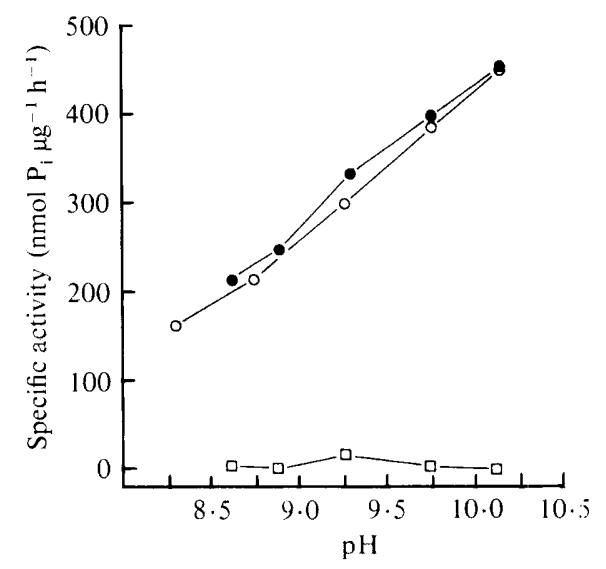

Fig. 8

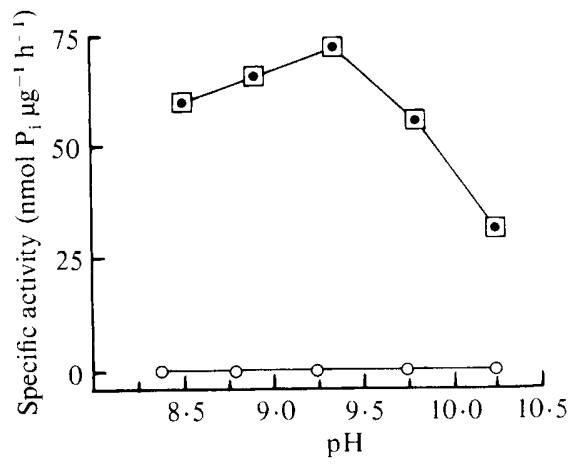

Fig. 9

Fig. 8. PMEase and 5'-NDase activities of a purified cell wall fraction. Cells were washed in wash buffer, resuspended in disruption buffer, disrupted by pressure cell and subjected to differential centrifugation according to the scheme in Fig. I (b). Assays were done with pNPP $(\bigcirc)$ or AMP $(O)$ at a final concentration of $2.5 \mathrm{~mm}$. Activities of $5^{\prime}$-NDase $(\square)$ were calculated by subtraction of the PMEase from the NMPase activities.

Fig. 9. PMFase and 5'-NDase activities of a cell wall-free microsomal fraction. Cells were washed in wash buffer, resuspended in disruption buffer, disrupted by shaking with glass beads and subjected to differential centrifugation according to the scheme in Fig. $1(a)$. Assays were done with pNPP $(O)$ or AMP ( at a final concentration of $2.5 \mathrm{~mm}$. Activities of $5^{\prime}$-NDase $(\square)$ were calculated by subtraction of the PMEase from the NMPase activit es.

physiological growth $\mathrm{pH}$ of $8 \cdot 5$. Whereas the PMEase activity in this diatom has been reported previously (Kuenzler \& Perras, 1965; Chiaudani \& Vighi, 1982), the existence of a 5 '-NDase has not. Kuenzler \& Perras (1965) did demonstrate that the phosphate from AMP could be used by this diatom, but they measured the appearance of the phosphate within the cells and, as they reported that the limiting factor was probably the rate of uptake rather than the rate of hydrolysis, it is not surprising that they also found the rate of use of the phosphate from AMP to be the same as that from glucose 6-phosphate or $\alpha$-glycerophosphate. A similar observation has been made for the dinoflagellate Amphidinium carterae, in which the rate of polyphosphate hydrolysis exceeds the rate of phosphate uptake (Solorzano \& Strickland, 1968); the situation is reversed in the diatom Skeletonema costatum (Solorzano \& Strickland, 1968). The presence of a 5'-NDase was not reported for either alga.

As the NMPase activity of intact $P$. tricornutum was greater than the PMEase activity at the physiological $\mathrm{pH}$ of 8.5 (and at $\mathrm{pH} 8$, the $\mathrm{pH}$ of sea water), the detection of the ability to liberate $\mathrm{P}_{1}$ from AMP may be more indicative of phosphate-deficiency in natural populations than the ability to hydrolyse pNPP, which depends on the presence of PMEase. Work with more species is required to see whether all algae have 5'-NDase activity. From an ecological standpoint, NMPs may be a source of phosphate for P. tricornutum. Unfortınately, there appear to be few published data for the concentration of NMPs in sea water. The total concentration of ATP, ADP and AMP has been reported to be about $3 \mathrm{nM}$ off the coast of California (McGrath \& Sullivan, 1981), but it is thought that the common occurrence of PMEase activities significantly affects measurements of NMPs in aquatic systems (Karl \& Craven, 1980).

The substrate affinity of the PMEase in P. tricornutum (about $50 \mu \mathrm{M}$ ) was similar to that reported for the enzyme in Chaetoceros affinis (Moller et al., 1975), which has a $K_{\mathrm{m}}$ of $20 \mu \mathrm{M}$. However, natural phytoplankton communities in Chesapeake Bay exhibit a PMEase with a $K_{\mathrm{m}}$ of less than $1 \mu \mathrm{M}$ (Taft et al., 1977); the authors concluded that PMEase activity may contribute significantly to phosphate-nutrition during much of the year in this bay. 
The PMEase activity of intact cells of P. tricornutum was reported by Kuenzler \& Perras (1965) as being firmly bound to the cells; they did not detect any substantial extracellular activity such as that seen in the present work or by Chiaudani \& Vighi (1982), although this could be due to a difference between the isolates of alga used. The similarity between the activities of the cellbound and extracellular PMEase (Fig. 2) with respect to $\mathrm{pH}$, and the fact that there was no detectable extracellular 5'-NDase is consistent with the view that the PMEase may be bound to the cell wall and the 5'-NDase to the plasma membrane. The increased enzyme activities after disruption (greater for the 5'-NDase than for the PMEase; Table 1) could have been due to the removal of diffusion barriers. Electron micrographs of sectioned intact cells show a considerable amount of membranous material between the cell wall and the plasma membrane. The nature of this material is under investigation but it may contain $5^{\prime}$-NDase activity which is not readily accessible to the substrate supplied externally to whole cells. Alternatively, disruption of the cells may release a soluble 5'-NDase activity. The 5'-NDase activity in the final supernatant is consistent with this view although this could have resulted from membrane vesicles which had not been sedimented during the (quite short) ultracentrifugation procedure. Repeated washing and recentrifugation of the microsomal fraction did not result in the loss of 5'-NDase activity, suggesting that the enzyme was firmly attached to membranes.

The presence of 5'-NDase activity in the cell wall fraction when cells were disrupted with glass beads (Table 1) was probably due to the presence of membranes with which this enzyme was associated in the partly disrupted valves. Repeated washing and recentrifugation of this fraction did result in a partial, though not total, removal of this activity.

The presence of PMEase activity in the chloroplast and mitochondria fraction (Table 1) would have been associated with the presence of cell wall fragments visible by phase-contrast and electron microscopy. Due to the density of the disruption buffer, some cell wall material would not have pelleted during the preceding low-speed centrifugation.

The success of the differential centrifugation scheme (Fig. 1b), after disruption of the cells by the pressure cell, was probably due to the inability of the low centrifugation forces to pellet any material other than the cell wall fragments. Differential centrifugation is a crude procedure leading to only partial purification of material by the size and density of the fragments. It is none the less an important procedure in attempts to isolate plasma membranes as it removes larger fragments and organelles which have similar densities to that of plasma membrane vesicles and therefore can not be separated by density gradient centrifugation (Leonard \& Hodges, 1980).

In membrane fractions from the diatom Nitzschia alba, the presence of an alkaline PMEase and of a 5'-NDase was demonstrated (Sullivan \& Volcani, 1974). However, protoplasts of this diatom were used and although $50 \%$ of the PMEase activity was pelleted in a fraction termed 'cell wall' by the authors, the actual composition of this fraction was not revealed. Neither enzyme could be used as a marker for plasma membranes in this diatom.

PMEase activity is associated with the cell wall in higher plants (e.g. clover; Dracup et al., 1984 ) and in the cyanobacterium Plectonema boryanum (Doonan \& Jensen, 1977). However, in organisms with no cell wall PMEase activity may be detected in the plasma membrane. The plasma membranes of the wall-less chrysophyte Ochromonas danica (Patri et al., 1974), and of the slime mould Dictyostelium discoideum (Lee et al., 1975) both exhibit a PMEase activity. The latter also exhibits a $5^{\prime}$-NDase activity and both enzymes develop during phosphate-deprivation but have different $\mathrm{pH}$ optima (Lee et al., 1975). The 5'-NDase activity has been used as a marker for plasma membranes (Gilkes \& Weeks, 1977).

From the results of the experiments described in this paper, it is concluded that the PMEase activity measured in intact cells of $P$. tricornutum is due to an enzyme located in the cell wall. The 5 -NDase activity of intact cells is not due to a wall-bound enzyme, but to a membrane-bound protein, presumably in the plasma membrane. It is not known if the extracellular PMEase released by phosphate-deficient cells results from the release of the wall-bound PMEase; electrophoretic studies are needed to examine this problem. The $5^{\prime}$-NDase activity can probably be used as a marker enzyme in attempts to isolate plasma membranes from $P$. tricornutum, provided that the cells are grown in phosphate-deficient medium in order to stimulate the production of the enzyme activity. 
The work described in this paper was funded by a grant from the SERC.

\section{FE FERENCES}

Chiaudani, G. \& Vighi, M. (1982). Muitistep approach to identification in Northern Adriatic eutrophied coastal waters. Water Research 16, 1161-1166.

DoOnan, B. B. \& Jensen, T. E. (1977). Ultrastructural localization of alkaline phosphatase in the bluegreen bacterium Plectonema boryanum. Journal of Bacteriology 132, 967-973.

Dracup, M. N. H., Barrett-Lennard, E. G., Greenway, H. \& Robson, A. D. (1984). Effect of phosphorus deficiency on phosphatase activity of cell walls from roots of subterranean clover. Journal of Experimental Botany 35, 466480.

FlynN, K. J. \& SYRETt, P. J. (1985). The development of the ability to take up L-lysine by the diatom Phaeodactylum tricornutum. Marine Biology 89, 317 325.

Gilkes, N. R. \& Weeks, G. (1977). The purification and characterization of Dictyostelium discoideum plasma membranes. Biochimica et biophysica acta 464. $142-256$

Goldman, J. C., McCarthy, J. J. \& Peavey, [). G. (1979). Growth rate influence on the chemical composition of phytoplankton in oceanic witers. Nature, London 279, 210215.

Karl, D. M. \& Craven, D. B. (1980). Effec:s of alkaline phosphatase activity on nucleotide mea surements in aquatic microbial communities. Applied and Entironmental Microbiology 40, 549-561.

Kuenzler, E. J. (1965). Glucose-6-phosphate utilization by marine algae. Journal of Phycology 1, 156158.

Kuenzler, E. J. \& Perras, J. P. (1965). Phosphatases of marine algae. Biological Bulletin 128, $271 \% 284$.

Lanzetta, P. A., Alvarez, L. J., Reinach, P. S. \& Candia, O. A. (1979). An improved assay for nanomole amounts of inorganic phosphate. Anclytical Biochemistry 100, 9597.

Lee, A., Chance, K., Weeks, C. \& Weeks, (i. (1975). Studies on the alkaline phosphatase and 5 -nucleotidase of Dictyostelium discoideum. Archines of Biochemistry and Biophysics 171, 407-417.

LeOnard, R. T. \& Hodges, T. K. (1980). The plasma membrane. In The Biochemistry of Plants, 1. The Plant Cell, pp. 163-182. Fdited by N. E. Tolbert. London: Academic Press.

MCGrath, S. M. \& Sullivan, C. W. (1981). Community metabolism of adenylates by microheterotrophs from the Los Angeles Harbor and Southern California coastal waters. Marine Biology 62, 217-226

Moller, M., Myklestad, S. \& Haug, A. (1975). Alkaline and acid phosphatase of the maine diatoms Chactoceros affinis var. willei (Gran) Hustedt and Skeletonema costatum (Grev.) Cleve. Journal of Experimental Marine Biology and Ecology 19, 217226.

Myklestad, S. \& Sakshaug, E. (1983). Alkaline phosphatase activity of Skeletonema costatum populations in the Trondheimsfjord. Journal of Plankton Research 5, 557-564.

Patri, N. J., Billmire, E. \& Aaronson, S. (1974). Isolation of the Ochromonas danica plasma membrane and identification of several membrane fractions. Biochimica et biophysica acta 373, 347-355.

Perry, M. J. (1972). Alkaline phosphatase activity in subtropical central North Pacific waters using a sensitive fluorimetric method. Marine Biology 15, 113-119.

Provasoli, L., Mclaughlin, J. J. A. \& Droop, M. R. (1957). The development of artificial media for marine algae. Archiv für Mikrobiologie 25, 392 428 .

RHEE, G.-Y. (1972). Competition between an alga and an aquatic bacterium for phosphate. Limnology and Oceanography: 17, 505-514.

Sakshaug, E., Graneli, E., Elbrachter, M. \& KAYSER, H. (1984). Chemical composition and alkaline phosphatase activity of nutrient saturated and phosphorus deficient cells of four marine dinoflagellates. Journal of Experimental Marine Biology and Ecolog! 77, 241-254.

SMith, R. E. H. \& KalfF, J. (1981). The effect of phosphorus limitation on algal growth rates: evidence from alkaline phosphatase. Canadian Journal of Fisheries and Aquatic Sciences 38, 14211427.

Solorzano, L. \& Strickland, J. D. H. (1968). Polyphosphate in sea water. Limnology and Oceanography 13, 515-518.

Stewart, A. J. \& Wetzel, R. G. (1982). Influence of dissolved humic materials on carbon assimilation and alkaline phosphatase activity in natural algal bacterial assemblages. Freshwater Biology 12, 369 380

Sullivan, C. W. \& Volcani, B. E. (1974). Isolation and characterization of plasma and smooth membranes of the marine diatom Nitzschia alha. Archires of Biochemistry and Biophysics 163, 2945.

TAFT, J. L., Loftus, M. E. \& TAYLOR, W. R. (1977). Phosphate uptake from phosphomonoesters by phytoplankton in the Chesapeake Bay. Limnology and Oceanography 22, 10121021.

Yoshida, S., Uemura, M., Niki, T., Sakai, A. \& Gusta, L. V. (1983). Partition of membrane particles in an aqueous two-polymer phase system and its practical use for purification of plasma membranes from plants. Plant Physiology 72, 105-114. 